\title{
Recent studies of synthetic antibody-based 3-MCPD determination technology
}

\author{
Penelitian terkini dari teknologi deteksi 3-MCPD berbasis antibodi sintesis
}

\author{
Hasim MUNAWAR ${ }^{1) *}$, Prima LUNA $^{2)}$, Irma KRESNAWATY ${ }^{3)} \&$ Happy WIDIASTUTI ${ }^{3)}$ \\ ${ }^{1)}$ Balai Besar Penelitian Veteriner, Jalan RE. Martadianata No. 30 Bogor 16114 \\ ${ }^{2)}$ Balai Besar Litbang Pasca Panen Pertanian, Jl. Tentara Pelajar No.12 A Bogor 16122 \\ ${ }^{3)}$ Pusat Penelitian Bioteknologi dan Bioindustri, Jl Taman kencana No 1 Bogor 16128
}

Accepted 13 November 2020/ Received 26 April 2021

\begin{abstract}
Abstrak
3-kloro-1,2-propanadiol (3-MCPD) diklasifikasikan oleh International Agency for Research on Cancer sebagai bahan bersifat karsinogen dan menjadi salah satu permintaan dari Uni Eropa yang mensyaratkan tingkat maksimum konsentrasi dari 3-MCPD dalam minyak sawit hingga 2,5 ppm. Meskipun metode GCMS dan HPLC-FLD yang dilaporkan menunjukan sensitifitas dan selektifitas yang tinggi pada pengukuran 3-MCPD, semua metode tersebut membutuhkan bahan kimia yang banyak dan proses pengerjaan dengan waktu yang lama untuk preparasi dan analisis sampel. Molecularly Imprinted Polymer (MIP) atau antibodi sintetik bisa digunakan untuk mengenali 3-MCPD. MIP lebih stabil dalam kondisi suhu dan pH yang ekstrim. Artikel ini akan membahas tentang pemanfaatan MIP pada ekstraksi sampel dan analisis sampel untuk mendeteksi 3-MCPD. MIP disintesis melalui polimerisasi monomermonomer yang bergugus fungsi di sekitar 3-MCPD sebagai targetnya. Kemudian, 3-MCPD diekstrak dari MIP dengan meninggalkan sisi aktif. Oleh karena itu, sisi-sisi aktif inilah yang dapat mengikat kembali 3-MCPD baik dengan ikatan kovalen maupun non kovalen. Simulasi komputer dan eksperimen dapat menginvestigasi komposisi dari MIP. MIP dapat diproduksi menjadi kolom ekstraksi berbasis MIP (MIPSPE) dan sensor berbasis MIP. Kedua produk tersebut menunjukan parameter analitik yang signifikan, yaitu nilai recovery lebih dari $90 \%$ dan limit deteksi kurang dari 2,5 ppm. Berdasarkan hasil kajian ini, penggunaaan MIP dapat fleksibel, digunakan baik untuk ekstraksi maupun analisis sampel dalam penentuan 3-MCPD. Teknologi berbasis MIP ini akan menjadi instrument yang prospektif untuk mendeteksi 3-MCPD. Produksi MIP dalam skala industri akan menjadi sebuah tantangan dalam memonitor tingkat konsentrasi 3-MCPD dalam produk minyak sawit.
\end{abstract}

[Kata kunci: 3-MCPD, molecularly imprinted polymer (MIP), kolom ekstraksi berbasis MIP, sensor berbasis MIP]

\begin{abstract}
3-Chloro-1,2-propanediol (3-MCPD) is classified by the International Agency for Research on Cancer as carcinogenic material. 3-MCPD will also become one of the European Union's requirements, proposing the maximum level of the 3-MCPD in palm oil until $2.5 \mathrm{ppm}$. Although the reported technologies GCMS and HPLC-FLD demonstrated high sensitivity and selectivity on 3MCPD determination, those technologies invest in chemical and time-consuming sample preparation and analysis. Molecularly imprinted polymer (MIP), or a synthetic antibody, can be used to recognize 3-MCPD. MIP is more robust under extreme environments such as temperature and $\mathrm{pH}$. This paper, therefore, aims to discuss the application of MIP on sample extraction and analysis to detect 3-MCPD. MIP is synthesized by polymerization of functional monomers surrounding 3-MCPD as a template. 3-MCPD is then removed from the MIP, leaving active cavities. Thus, these sites can either covalently or non-covalently rebind to 3-MCPD. Computational or empirical studies could investigate the composition of MIP. MIP can be manufactured as MIP-based solid phase extraction (MIPSPE) and MIP-based sensor. Both applications showed significant analytical parameters, such as recovery higher than $90 \%$ and detection limit lower than 2.5 ppm. Therefore, the application of MIP can be flexible for sample preparation and analysis on the 3-MCPD determination. MIP-based technology would be a prospective instrument to detect 3MCPD. In the future, producing MIP on an industrial scale will be a challenge to monitor the 3-MCPD level in palm oil.
\end{abstract}

[Keywords: 3-MCPD, molecularly imprinted polymer (MIP), MIP-based SPE, MIP-based sensor] 


\section{Introduction}

3-chloro-1,2-propanediol (3-MCPD) is one of the critical substances for palm oil exporters, particularly in Indonesia. This material will be one of the palm oil requirements for export trade proposed by the European Commission (Suwastoyo, 2020). At this moment, the valid regulation for 3-MCPD is only focussing on hydrolyzed vegetable protein and soy sauce with a maximum level of $0.02 \mathrm{ppm}$ (EU, 2018). Surprisingly, the new regulation for 3-MCPD conferred in palm oil up to $2.5 \mathrm{ppm}$ has recently been proposed by the European Commission. Although this regulation is still being discussed, it is necessary to develop innovative technology for 3-MCPD control.

The incidence of 3-MCPD was first reported in 1984 by Cerbulis and friends (Cerbulis et al., 1984). Fatty acid ester and bound 3-MCPD were found in goat's milk. Free and bound 3-MCPDs have also been identified and reported by Zelinková et al. (2006) in several edible oils such as virgin seed oils, virgin olive oils, virgin germ oils, refined seed oils, and refined olive oils from several European countries such as France, Italy, Germany, Spain, Greece, the Czech Republic, and Hungary. Some researchers in Indonesia, Lanovia and colleagues (Lanovia et al., 2014) reported that 3-MCPD was present in palm oil with a 14-35 ppm concentration range. Concerning the above, it is said that the presence of 3-MCPD or derivatized 3MCPD in our foodstuffs should be more attentive.

The International Agency for Research on Cancer (IARC) reported the carcinogenicity of 3MCPD in their monograph book (IARC, 2013), although no data were found in human cases. Several methods, such as oral and subcutaneous administration, and dermal application, have investigated the incidence of tumors in mice and rats (Van Duuren et al., 1974; Weisburger et al., 1981; Cho et al., 2008; Jeong et al., 2010), showing damage to multiple organs, such as liver and kidney. From these data, it is believed that to investigate the 3-MCPD residue in our food, the technique for controlling 3-MCPD is essential; therefore, organ damage would be immediately anticipated.

This paper aims to discuss the relevant information on the latest technology based on molecularly imprinted polymer, particularly its performance and application in actual samples. General information on 3-MCPD has been provided, including physical and chemical properties. The authors also described earlier technologies from the past, such as Gas Chromatography-Mass Spectroscopy (GC-MS) and High-Performance Liquid Chromatography Fluorescence Detector (HPLC-FLD). Molecularly Imprinted Polymer (MIP) was mentioned as a synthetic antibody, including composition, production, and for solid-phase extraction (SPE) and sensor application. In the end, the future development of MIP-based technology has been identified from previously reported developments.

\section{3-MCPD: physical and chemical characteristics}

The 3-MCPD has more than ten names and 3monochloro-1,2-propanediol is the popular one (IARC, 2013). 3-MCPD has a molecular weight of $110.54 \mathrm{gmol}^{-1}$ and is soluble in water, alcohol, diethyl ether, and acetone. From the chemical formula, 3-MCPD contains one chloride and two hydroxyl groups (Figure 1). It is called the unbound or free 3-MCPD. Other forms of 3MCPD are bound 3-MCPD containing the ester chain and could be hydrolyzed to be a free form (Barocelli et al., 2011; Abraham et al., 2013).

The formation of 3-MCPD can be triggered in palm oil during fat frying by sodium chloride $(\mathrm{NaCl})$, water content, heating temperature, and heating time (Zhou et al., 2014). From these results, careful processing of palm oil could be recommended. There are many cases in which 3MCPD may be formed during degumming (Zulkurnain et al., 2012; Matthäus \& Pudel, 2013), neutralisation (Matthäus \& Pudel, 2013), bleaching (Razak et al., 2012; Zulkurnain et al., 2012) and deodorisation (Franke et al., 2009; Hrncirik \& van Duijn, 2011). Due to these issues, the 3-MCPD is easily left in food.

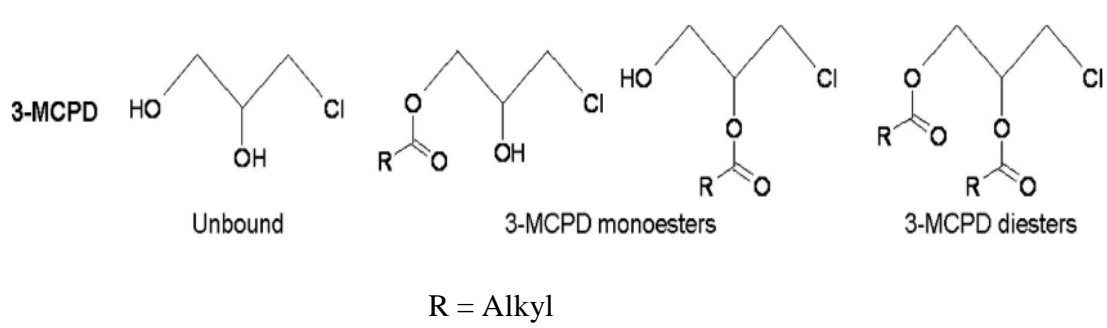

Figure 1. Chemical structures of free 3-MCPD and bound 3-MCPD Gambar 1. Struktur kimia 3-MCPD bebas dan 3-MCPD terikat

Source: modified from Andres and colleagues (2013)

Sumber: dimodifikasi dari Andres et al. (2013) 


\section{The current technologies for 3-MCPD detection}

Most of the techniques used to detect 3-MCPD are based on chromatography methods. One of them is GC-MS. This method is probably not easily accessible due to lengthy procedures for sample extraction and analysis, even though the European Commission recommended the GC-MS method (EU, 2014). Miyazaki and colleagues (Miyazaki et al., 2012) tried to analyze 3-MCPD of spiked palm oil. The oil sample was hydrolyzed and derived before going to GC-MS. It is claimed that 3-MCPD was read as 3-MCPD derivatization, i.e., dipalmitic 3-MCPD dioleic, 3-MCPD, 3MCPD dilinoleic, 3-MCPD 1-palmitate, and 3MCPD 1-oleate. Results from a recovery test of 93$106 \%$ were quite good. They also applied this method to other samples with a different matrix, such as rapeseed oil, safflower oil, olive oil, soya bean oil, corn oil, rice bran oil, sesame oil, and sunflower oil, with a recovery test of between 89 and $108 \%$.

The following method is HPLC-FLD, reported by $\mathrm{Hu}$ et al. (2013), testing 3-MCPD in vegetable oils, including corn oil, rice bran oil, and soya oil. The procedure is different from the one before. The 3-MCPD was cleaved by chloroacetaldehyde and derivatized by adenine, finally producing $\varepsilon$ Ade (1$\mathrm{N}^{6}$-ethenoadenine). FLD then analyzed this final product through Fluorescence Derivation. The results of this experiment were terrific since the recovery test was approximately $93-97 \%$, and the detection limit was $0.36 \mathrm{ppb}$. The last example is from Lanovia et al. (2014), measured free 3MCPD and total 3-MCPD in palm oil measured by GC-MS. The instrument was modified by the Weißhaar method (Weißhaar, 2008). The experiments claimed that the results were outstanding for several reasons, such as concentration range: $0.008-0.377 \mathrm{ppm}$, detection limit: 0.06 ppm and recovery test: 96-113\%.

Thus far, the current technologies (GCMS and HPLC FLD) for 3-MCPD detection show powerful results even though they are still laborious and time-consuming. The methods use many chemicals and are not easy for people to operate the instrument. Besides, there is no guarantee that 3MCPD will be fully converted to its derivatization product event though the methods enable to measure the derivatisation of 3-MCPD. As a result, MIP-based technology could minimize the problem of those technologies to identify better 3MCPDs than previously reported (Table 1).

Table 1. Comparison of the techniques for 3-MCPD analysis between MIP-based technologies and conventional methods (GC-MS and HPLC-FLD)

Tabel 1. Perbandingan metode analisis 3-MCPD antara teknologi berbasis MIP dan Metode konvensional (GC$M S$ and HPLC-FLD)

\begin{tabular}{|c|c|c|}
\hline $\begin{array}{c}\text { Methods for 3-MCPD } \\
\text { analysis } \\
\text { Metode analisis 3-MCPD }\end{array}$ & $\begin{array}{c}\text { Advantages } \\
\text { Kelebihan }\end{array}$ & $\begin{array}{c}\text { Disadvantages } \\
\text { Kekurangan }\end{array}$ \\
\hline GC-MS & $\begin{array}{l}\text { - High sensitivity and selectivity } \\
\text { - Enable to detect multianalyte } \\
\text { with different analogs }\end{array}$ & $\begin{array}{l}\text { - Long protocol for sample preparation } \\
\text { consuming the plenty of chemicals } \\
\text { - Long procedure for sample analysis; } \\
\text { therefore, a trained person is needed } \\
\text { - The maintenance fee is expensive } \\
\text { - The price for sample analysis is } \\
\text { expensive }\end{array}$ \\
\hline HPLC-FLD & $\begin{array}{l}\text { - High sensitivity and selectivity } \\
\text { - Enable to detect multianalyte } \\
\text { with different analogs }\end{array}$ & $\begin{array}{l}\text { - Long protocol for sample preparation } \\
\text { consuming the plenty of chemicals } \\
\text { - Long procedure for sample analysis; } \\
\text { therefore, a trained person is needed } \\
\text { - The maintenance fee is expensive } \\
\text { - The price for sample analysis is } \\
\text { expensive }\end{array}$ \\
\hline MIP-based technologies & $\begin{array}{l}\text { - Short protocol for sample } \\
\text { preparation consuming less } \\
\text { chemicals } \\
\text { - Short procedure for sample } \\
\text { analysis and no need to hire a } \\
\text { trained person } \\
\text { - Low cost for maintenance fee } \\
\text { - The price for sample analysis is } \\
\text { cheap } \\
\text { - High sensitivity and selectivity }\end{array}$ & $\begin{array}{l}\text { - Cannot detect multianalyte with } \\
\text { different analogs because the MIP is } \\
\text { produced for only one single target. }\end{array}$ \\
\hline
\end{tabular}




\section{Molecularly Imprinted Polymer (MIP)-based technologies}

\section{MIP composition for 3-MCPD}

In general, several chemicals such as functional monomers (FMs), crosslinkers (CL), initiators (I), and solvents (S) are needed to produce MIP. FMs are critical materials because these chemicals should have a proper interaction directly with 3MCPD; therefore, the MIP has an active cavity recognizing 3-MCDP correctly. Published articles ( Leung et al., 2003; Li et al., 2014; Sun et al., 2014; Fang et al., 2019; Yaman et al., 2020) show that FMs for 3-MCPD had different materials among experiments (Table 2). It is indicated that FM materials can be flexible as long as these chemicals can react with 3-MCPD. Similarly, the solvents used in each MIP production are different depending on the solubility of FMs and 3-MCPDs. These reagents are also crucial to produce MIP on the polymerization step. CL is probably a similar reagent for different MIP production methods and different MIP applications, unlike FMs and solvents. Similarly, the use of an initiator occurred, as shown in Table 2. For instance, ethylene glycol dimetacrylate and Azodi isobutyro nitrile are popular materials as CL and Initiator, respectively. They can be commonly used for bulk polymerization and both sample preparation and analysis purposes. Besides, not all of the MIP production needs CL and Initiator. For example, Sun et al. (2014) did not use CL, while Yaman et al. (2020) did not use I to generate MIP. The main reason is that they used the method of electropolymerization for the construction of MIP. Therefore, the composition of the MIP is very versatile, and it would be an opportunity for the researcher to explore the new composition of the MIP occasionally.
The role of each component of the MIP is accurate because every element supports the quality of the MIP. For example, the FMs form active MIP sites. In this way, FMs should have an appropriate functional group that can interact either covalently or non-covalently with 3-MCPD. Generally, hydrogen bonding is a type of interaction between FMs and 3-MCPD because this interaction is the strongest than other bonding. Attention should be paid to the chemical structures of 3-MCPD to select the best FMs. Here, 3-MCPD contains two hydroxyls and one chloride, forming a fast hydrogen bonding. It appears that the FMs for 3-MCPD is abundant. For example, methacrylic acid (Table 2) can be used appropriately and tested experimentally to react with 3-MCPD (Li et al., 2014; Fang et al., 2019).

Other compositions, such as $\mathrm{Cl}$, also have specific responsibility for maintaining interaction between FMs and 3-MCPD; therefore, the active cavity on the MIP is more stable and rigid. The best CL should have double or triple bonds because they will help forming the MIP body. The existence of CL is designed to control polymer morphology, such as swelling and mesh size, to stabilize polymer binding sites and to convey the mechanical stability of matrix polymers (Mayes \& Mosbach, 1996; Yu \& Mosbach, 2000; Wong et al., 2015; Mane et al., 2015). Furthermore, the initiator is undoubtedly a vital material forming a free radical substance, and this part will initiate polymerization for generating MIP. However, in some cases, the initiator operates optimally under light, thermal or chemical conditions (Mijangos et al., 2006). Finally, the solvent holds the essential component as a medium for the production of MIP and provides the opportunity for other components to interact and form the morphology of MIP.

Table 2. The composition, method, and application for 3-MCPD imprinted polymer

Tabel 2. Komposisi, metode, dan aplikasi dari 3-MCPD imprinted polymer

\begin{tabular}{|c|c|c|c|c|c|c|}
\hline \multicolumn{4}{|c|}{ MIP composition/ Komposisi MIP } & \multirow{2}{*}{$\begin{array}{l}\text { Method } \\
\text { Metode }\end{array}$} & \multirow{2}{*}{$\begin{array}{c}\text { Application } \\
\text { Aplikasi }\end{array}$} & \multirow{2}{*}{$\begin{array}{l}\text { Reference } \\
\text { Referensi }\end{array}$} \\
\hline FM & $\mathrm{CL}$ & I/ES & $S$ & & & \\
\hline $\begin{array}{l}\text { p-amino } \\
\text { thiophenol }\end{array}$ & - & $\begin{array}{l}\text { Tetrabutyl } \\
\text { ammonium } \\
\text { perchlorate }\end{array}$ & Methanol & $\begin{array}{c}\text { electropoly } \\
\text { merisation }\end{array}$ & $\begin{array}{l}\text { sample } \\
\text { analysis }\end{array}$ & $\begin{array}{c}\text { (Sun et al., } \\
\text { 2014) }\end{array}$ \\
\hline $\begin{array}{l}\text { 4-vinyl phenyl } \\
\text { boronic acid }\end{array}$ & \multirow{3}{*}{$\begin{array}{l}\text { Ethylene } \\
\text { glycol } \\
\text { dimethacr } \\
\text { ylate }\end{array}$} & \multirow{3}{*}{$\begin{array}{l}\text { Azodi } \\
\text { isobutyro } \\
\text { nitrile }\end{array}$} & chloroform & \multirow{3}{*}{$\begin{array}{c}\text { bulk } \\
\text { polymeriza } \\
\text { tion }\end{array}$} & $\begin{array}{l}\text { sample } \\
\text { analysis }\end{array}$ & $\begin{array}{l}\text { (Leung et } \\
\text { al., 2003) }\end{array}$ \\
\hline Methacrylic acid & & & $\begin{array}{l}\text { Methanol: } \\
\text { water }\end{array}$ & & $\begin{array}{l}\text { sample } \\
\text { extraction }\end{array}$ & $\begin{array}{c}\text { (Li et al., } \\
\text { 2014) }\end{array}$ \\
\hline & & & ethanol & & $\begin{array}{l}\text { sample } \\
\text { analysis }\end{array}$ & $\begin{array}{c}\text { (Fang et al., } \\
\text { 2019) }\end{array}$ \\
\hline Pyrrole & $\begin{array}{c}\text { Graphene } \\
\text { oxide }\end{array}$ & - & Methanol & $\begin{array}{c}\text { Electropoly } \\
\text { merization }\end{array}$ & $\begin{array}{l}\text { sample } \\
\text { analysis }\end{array}$ & $\begin{array}{l}\text { (Yaman et } \\
\text { al., 2020) }\end{array}$ \\
\hline
\end{tabular}

\section{Notes:}

$\mathrm{FM}=$ Functional Monomer, $\mathrm{CL}=$ Cross Linker, $\mathrm{I} / \mathrm{ES}=$ Initiator/Electrolyte Solvent, $\mathrm{S}=$ solvent

Keterangan:

$F M=$ monomer fungsional, $C L=$ bahan pengikat, $I / E S=$ inisiator/pelarut elektrolit, $S=$ pelarut 
There are many reported MIP production methods, such as conventional polymerization (e.g., bulk polymerization, suspension polymerization) (De Smet et al., 2009), supercritical fluid technology (Scholsky, 1993), solid-phase synthesis (MIP in nanoscale, called nanoMIP) (Munawar et al., 2020a) and electropolymerisation (Munawar et al., 2020b). Unfortunately, according to the published article on the development of MIP for 3-MCPD, only two methods are described here, bulk polymerization (Li et al., 2014) and electropolymerization (Sun et al., 2014; Yaman et al., 2020).

\section{MIP based SPE (MIPSPE) for 3-MCPD}

The preparation of MIPSPE is more straightforward than reported SPE, and there is no need to spend many chemicals. Figure 2 showed how to form the MIP for 3-MCPD modified from Li et al. (2014). The silica gel was activated by sodium hydroxide and silanized by APTES, obtaining the modified silica gel. This silica gel was then used for copolymerization of MAA (FM) and EGDMA (CL) in the presence of 3-MCPD. Copolymerization occurred due to the presence of AIBN, resulting in a non-covalent MAA and 3MCPD complex. In this case, 3-MCPD was predicted to form hydrogen bonding with MAA (Figure 2(a)). MCPD was removed by methanol: water $(9: 1, \mathrm{v} / \mathrm{v})$ to obtain pure MIP. Li also provides computational simulation data to prove the interaction between 3-MCPD and MAA (Figure 2b). They claim that the best ratio is 1:2 for 3-MCPD and MAA, respectively, for MIP production. In addition, the morphology of the produced MIP for 3-MCPD was characterized using SEM. FTIR also observed the identification of the structure of MIP. The MIP profile could, therefore be more comprehensive and reliable.

The quality of the MIP-based SPE can be seen objectively compared to the previous SPE (Table 3) concerning analytical parameters such as the recovery and detection limit or the type of reagent used. Thus, it can be seen which SPEs are more efficient, effective, and safe. Unfortunately, not much data has been found on the development of MIP-based SPE for 3-MCPD. There are probably few commercialized MIPSPEs; therefore, MIP may be unknown to some stack holders. This case shows that it is necessary to disseminate the benefit of MIP and its application to stack holders or users.

In general, MIPSPE has outstanding accuracy in binding 3-MCD compared to other SPEs. The recovery test of MIPSPE is higher than 90\%, and the limit detection is around $0.002 \mathrm{ppm}$, indicating that the MIP was a powerful application for sample extraction. In addition, an elution solvent is not much more organic than the others, only acetonitrile and water. Therefore, MIPSPE is safer than the other SPEs using more organic solvents.

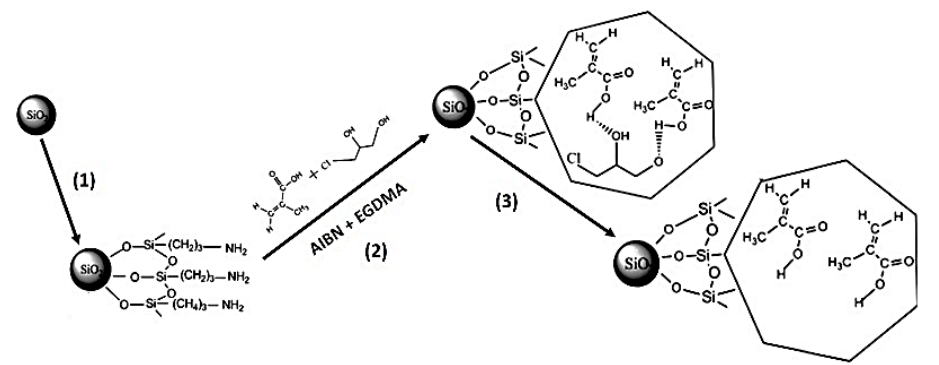

(a)

Figure 2 (a) Illustration of MIP production: (1) activation and silanization of silica gels (2) copolymerization of MIP on the surface of modified silica gels (3) removal of 3-MCPD for getting active cavities of MIP. (b) Associated complexes formed between 3-MCPD and MAA; the dotted lines indicate the hydrogen bonds using HyperChemV8.0.1.

Gambar 2 (a) Ilustrasi dari produksi MIP: (1) aktivasi dan silanisasi dari gel silika (2) kopolimerisasi MIP pada permukaan gel silika yang sudah dimodifikasi (3) pelepasan 3-MCPD untuk mendapatkan sisi aktif dari MIP. (b) Kompleks senyawa antara 3-MCPD dan MAA; garis titik titik mengindikasikan ikatan hydrogen menggunakan HyperChemV8.0.1.

Source: modified from Li et al. (2014)

Sumber: dimodifikasi dari Li et al. (2014)

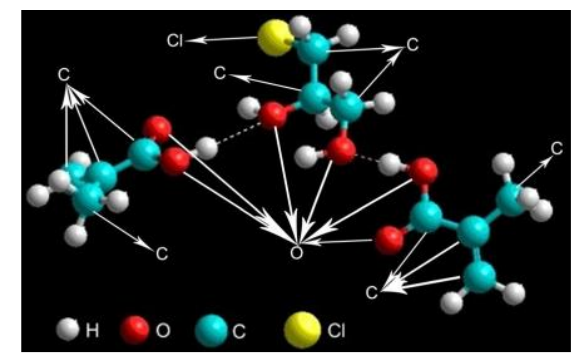

(b) 
MIP-based sensor for 3-MCPD

The next application, MIP, may also be used for sample analysis. Yaman et al. (2020) indicated that the MIP might be manufactured as a 3-MCPD sensor. Based on its outcome, this sensor is assumed to be quite good. The sensor performance was worked on the concentration range at 5-500 $\mathrm{nM}$ and the detection limit was $1.82 \mathrm{nM}$. The interesting point is how they manufactured the sensor using MIP (Figure 3), even though they still used old-fashioned electrode systems, including pencil electrode graphite (working electrode), Platinum wire (counter electrode), and $\mathrm{Ag} / \mathrm{AgCl} / 3$
$\mathrm{M} \mathrm{KCl}$ (reference electrode), instead of the screenprinted electrode used recently by so many sensor developers.

Manufacturing MIP-based sensor uses electropolymerization that is simpler than bulk polymerization. Here, Yaman and colleagues (Yaman et al., 2020) used a pencil graphite electrode (PGE) as a working electrode where the MIP attachment is located. The protocol is a onetime step, but they instantly get both the MIP and the MIP-based sensor. For this reason, electropolymerization is not complicated and is also more economical because few chemicals are used. Figure 3 shows the production of MIP and

Table 3. Comparison of sample extraction using MIPSPE and other SPEs

Tabel 3. Perbandingan ekstraksi sampel dengan MIPSPE dan SPE lain

\begin{tabular}{|c|c|c|c|c|c|}
\hline $\begin{array}{c}\text { Type of sample } \\
\text { Tipe sample }\end{array}$ & $\begin{array}{c}\text { Type of SPE } \\
\text { Tipe SPE }\end{array}$ & $\begin{array}{l}\text { Reagent } \\
\text { Pelarut }\end{array}$ & $\begin{array}{l}\text { Recovery } \\
\text { Rekoveri } \\
(\%)\end{array}$ & $\begin{array}{c}\text { LoD } \\
\text { Limit deteksi } \\
(\mathrm{ppm})\end{array}$ & $\begin{array}{l}\text { Reference } \\
\text { Referensi }\end{array}$ \\
\hline Soya sauce & MIP SPE & $\begin{array}{l}\text { acetonitrile: } \\
\text { water }\end{array}$ & 93 & 0.002 & (Li et al., 2014) \\
\hline $\begin{array}{l}\text { Cookies and } \\
\text { Margarine }\end{array}$ & $\begin{array}{l}\text { diatomaceous } \\
\text { earth extraction }\end{array}$ & $\begin{array}{l}\text { ethyl ether: } \\
\text { hexane }\end{array}$ & $99-108$ & NA & $\begin{array}{l}\text { (Becalski et al., } \\
\text { 2015) }\end{array}$ \\
\hline $\begin{array}{l}\text { Soy sauce, } \\
\text { dehydrated soup, } \\
\text { toasted bread, } \\
\text { vegetable oils, } \\
\text { salami, sausage, } \\
\text { and cheese }\end{array}$ & $\begin{array}{l}\text { ExtrelutÕ NT20 } \\
\text { cartridges }\end{array}$ & ethyl acetate & $92-100$ & NA & $\begin{array}{l}\text { (Retho \& } \\
\text { Blanchard, } \\
\text { 2005) }\end{array}$ \\
\hline Vegetable oil & $\begin{array}{l}\text { C18 powder- } \\
\text { packed syringe }\end{array}$ & $\begin{array}{l}\text { acetonitrile: 2- } \\
\text { propanol }\end{array}$ & $94-108$ & $0.0001-0.02$ & $\begin{array}{l}\text { (C. Li, Nie, } \\
\text { Zhou, \& Xie, } \\
\text { 2015) }\end{array}$ \\
\hline $\begin{array}{l}\text { Infant Formula } \\
\text { Milk Powder } \\
\end{array}$ & $\begin{array}{l}\text { alkaline diatomite } \\
\text { SPE column }\end{array}$ & $\begin{array}{l}\text { acetic ether: } \\
\text { diethyl ether }\end{array}$ & $98-111$ & 30 & $\begin{array}{l}\text { (Wang et al., } \\
\text { 2016) }\end{array}$ \\
\hline Corn oil & $\begin{array}{l}\text { DVB/CAR/PDMS } \\
\text { packed column }\end{array}$ & NA & 93 & $0.004-0.005$ & $\begin{array}{l}\text { (Xu, Jin, Yang, } \\
\text { Rao, \& Chen, } \\
\text { 2020) }\end{array}$ \\
\hline Extra virgin olive & $\begin{array}{l}\text { (Si-SAX and } \\
\text { PSA)-packed SPE } \\
\text { tube and (Z-Sep+ } \\
\text { and PSA)-packed } \\
\text { SPE }\end{array}$ & $\begin{array}{l}\text { diethyl ether: } \\
\text { hexane and } \\
\text { ethyl acetate: } \\
\text { acetonitrile }\end{array}$ & $71-123$ & $10-20$ & $\begin{array}{l}\text { (Custodio- } \\
\text { Mendoza et al., } \\
\text { 2018) }\end{array}$ \\
\hline
\end{tabular}

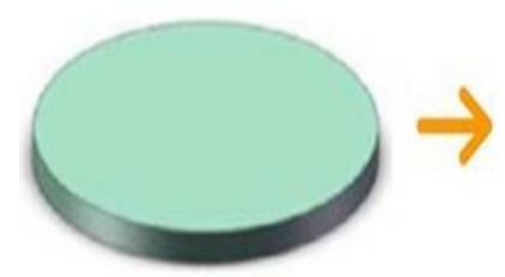

a) PGE

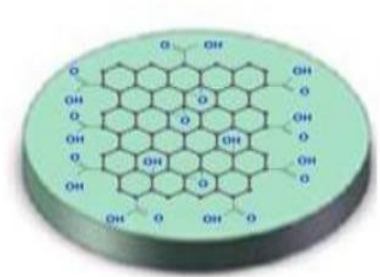

b) GO/PGE

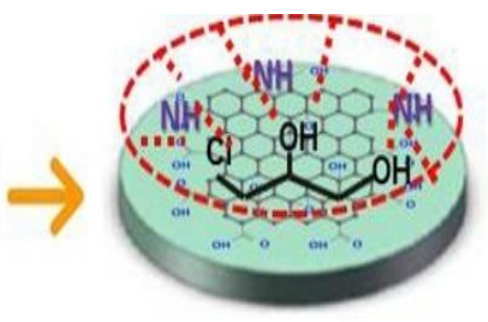

c) MIP(OPPy)-GO/PGE

Figure 3. The illustration of MIP-based sensor for 3-MCPD using pencil graphite electrode (PGE) Gambar 3. Ilustrasi dari sensor berbasis MIP untuk 3-MCPD menggunakan elektroda grafit pensil Source: modified from Yaman et al. (2020) Sumber: dimodifikasi dari Yaman et al. (2020) 
sensor. Step one, the graphene oxide (GO) was immobilized on the surface of the PGE. The pyrrole and 3-MCPD were then electropolymerized by Cyclic Voltammetry in optimum condition (Britton Robinson buffer, $\mathrm{pH}$ 4), potential range $0.0-+1.2 \mathrm{~V}$ (vs. $\mathrm{Ag} / \mathrm{AgCl}$ ), scan rate $50 \mathrm{mVs}^{-1}$, five cycles) on the GO-modified PGE (GO / PGE) surface. The last step was to wash the PGE with methanol: acetic acid $(9: 1, \mathrm{v} / \mathrm{v})$ to remove 3-MCPD from the system and leave the active MIP-based sensor (MIP(oPPy)/GO / PGE) cavities. The sensor is finally used for 3-MCPD detection on actual samples, soya sauces from the local market, using electrochemical impedance spectroscopy (EIS) with the optimum setting (AC potential $+0.20 \mathrm{~V}$, frequency range $0.1 \mathrm{~Hz}-100$ $\mathrm{kHz}$, amplitude ten $\mathrm{mV}$, ferri/ferrocyanide redox system). However, the data is likely to be validated to determine the recovery percentage in further study; therefore, the sensor is more reliable.

Sun and Colleagues (Sun et al., 2014) also applied MIP on sensor technology. However, the manufacturing process of the sensor is more complicated than the previous explanation, even though both used the same conventional electrode system. Herein, they used a modified carbon glass electrode (GCE) as a working electrode, a platinum wire as a counter electrode, and a saturated carbon electrode (SCE) as a reference electrode. Therefore, it is believed that there is an opportunity to develop a 3-MCPD sensor with a screen-printed electrode because it would be more portable and moveable. The sensor was manufactured in several stages (Figure 4) because the GCE should be modified by tetrachloroaurate (III) acid (HAuCl4) to form $\mathrm{Au}$ nanoparticles (AuNPs) deposit. The surface of the AuNP modified GCE (AuNPs / GCE) was then self-assembled by $p$-amino thiophenol ( $p$-ATP) through interaction between the gold and thiol groups (-SH) of the p-ATP to form an $\mathrm{Au}-\mathrm{S}$ bond. The 3-MCPD was continuously immobilized on that electrode, employing hydrogen bonding between the amino groups of $p$-ATP and the hydroxyls of 3-MCPD. Finally, the MIP was electropolymerized by Cyclic Voltammetry with optimum condition (10 cycles, potential range $-0.3-+1.2 \mathrm{~V}$, scan rate $50 \mathrm{mVs}^{-1}$ ).

The outstanding results have been reported, although the protocol for manufacturing the MIPbased sensor has been complicated. The produced sensor was tested for its 3-MCPD solution with a concentration range of $1.0 \times 10^{-17}$ to $1.0 \times 10^{-13} \mathrm{M}$, and the sensor is quite sensitive because the detection limit is lower than $1 \mathrm{nM}$. Soya sauce was also used for the recovery test, resulting in a recovery percentage of more than $90 \%$. There is, however, no data on the consistency of the sensor during the time of storage and no explanation of the sensor's reproducibility.

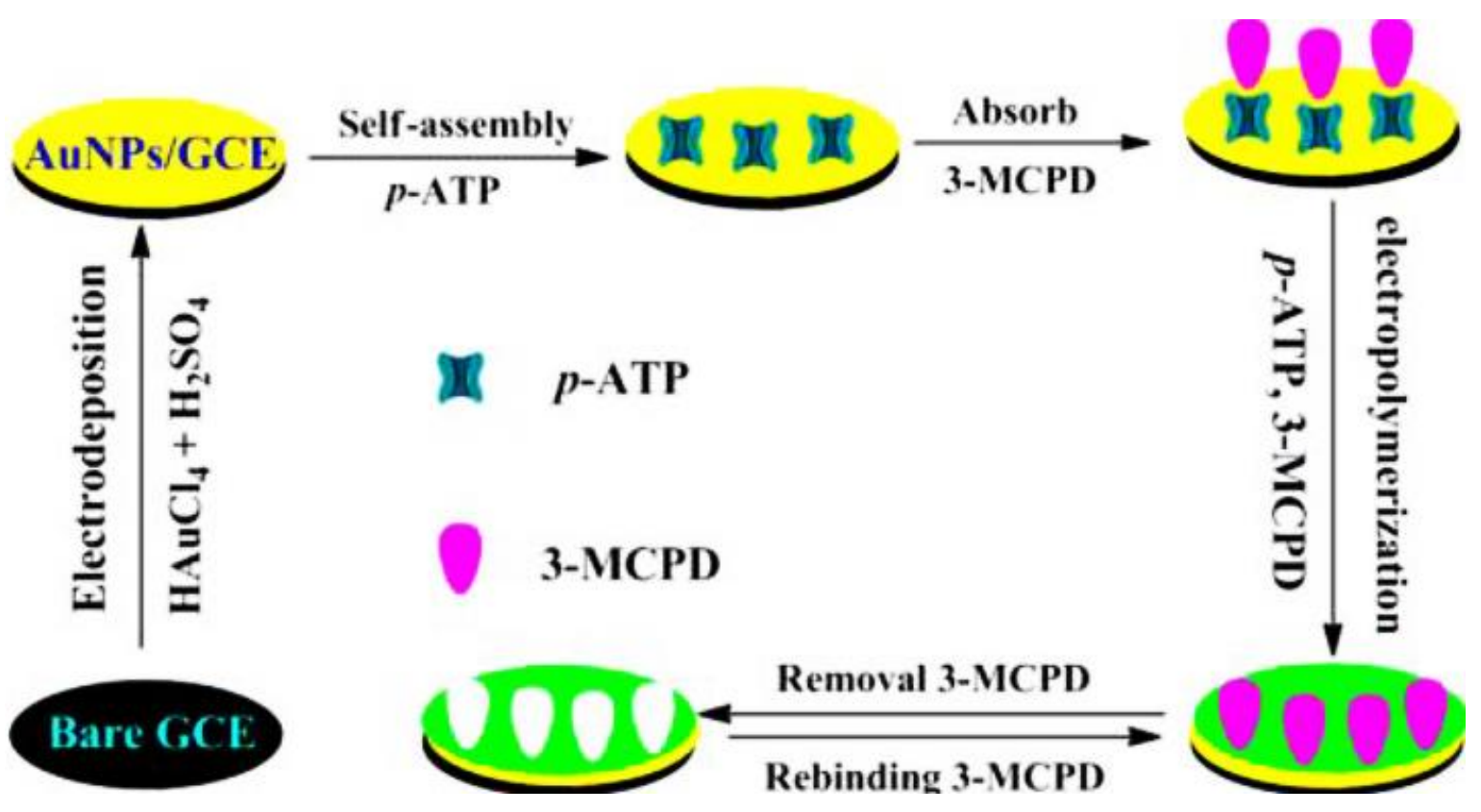

Figure 4. The illustration of MIP-based sensor for 3-MCPD using glassy carbon electrode (CGE)

Gambar 4. Ilustrasi dari sensor berbasis MIP untuk 3-MCPD dengan menggunakan elekroda karbon gelas

Source: adapted from Sun et al. (2014)

Sumber: diadaptasi dari Sun et al. (2014) 


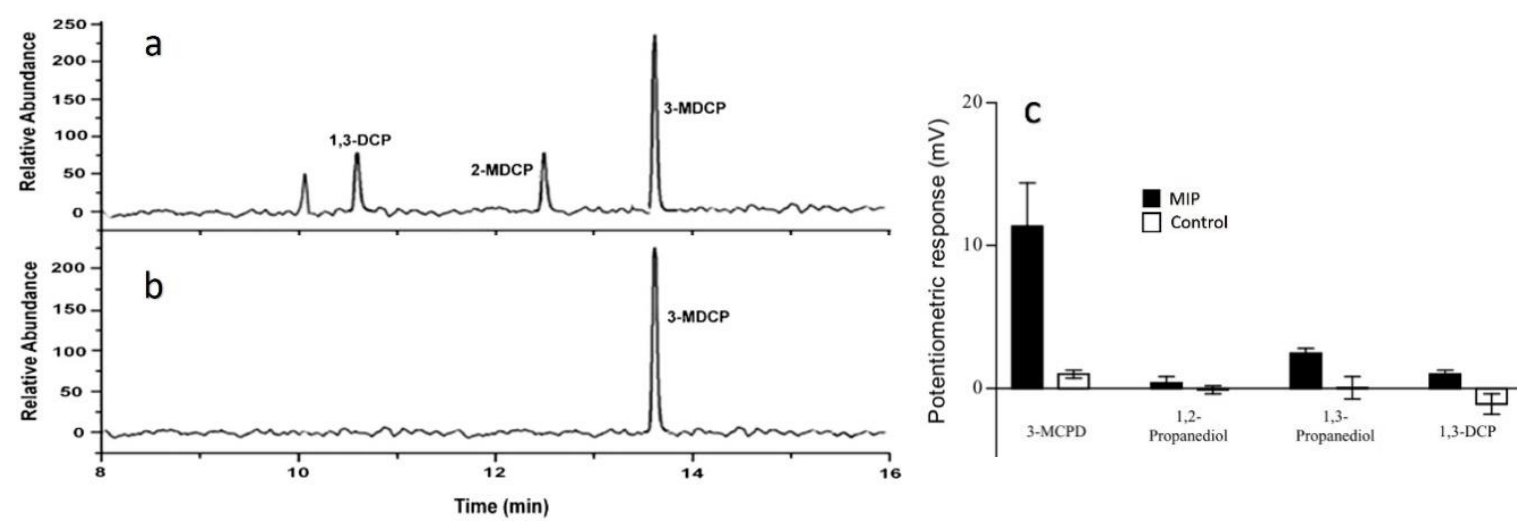

Figure 5 Chromatograms of the mixture solution (3-MCPD, 2- MPCD, and 1,3-DCP) without (a) and with (b) MIP-SPE column. (c) The selectivity testing of the MIP-based sensor on 3-MCPD and other analogs diols (1,2-propanediol; 1,3-propanediol; and 1,3-DCP)

Gambar 5. Kromatogram dari larutan campuran (3-MCPD, 2- MPCD, and 1,3-DCP) tanpa (a) dan dengan (b) MIP-SPE column. (c) Uji selektifitas dari sensor berbasis MIP pada 3-MCPD dan senyawa diols lainnya (1,2-propanediol; 1,3-propanediol; and 1,3-DCP)

Source: adapted from Leung et al., (2003) and Li et al., (2014)

Sumber: diadaptasi dari Leung et al., (2003) dan Li et al., (2014)

The selectivity of MIP-based technologies

MIP selectivity was reported from $\mathrm{Li}$ and Colleagues (2014), showing results from MIPbased SPE. Figures $5 \mathrm{a}$ and $5 \mathrm{~b}$ illustrated the chromatograms of mixture solution including 3MCPD, 2-MPCD, and 1,3-DCP, without and with MIP-based SPE pre-treatment. The performance of MIP was very outstanding in distinguishing 3MCPD from Li's work with other targets. In addition, the selectivity of MIP was observed by Leung et al. (2003), producing an electrochemical sensor based on MIP. The 3-MCPD sensor may differ from other analog diols such as 1,2propanediol and 1,3-propanediol, and 1,3-DCP (Figure 5c). It appears that the sensor was unable to recognize the other targets as the same as those responses from the control material. Similar results have been shown in the following reports (Sun et al., 2014; Fang et al., 2019; Yaman et al., 2020). More analog diols (e.g., glycerol, 2,3-DCP, ethylene glycol, 2-MCPD, L-glutamic acid, Ltryptophan and L-phenylalanine) were used to demonstrate the selectivity of MIP in the flatform sensor, and the performance of MIP did not significantly recognize those targets. Unfortunately, no observation has been reported about the selectivity of MIP on free and bound 3MCPDs. It would be an excellent opportunity for future researchers to investigate this challenge.

\section{Conclusion}

Molecular Imprinting Polymer (MIP) technology is an alternative method for controlling 3-MCPD with many benefits. The few chemicals used are advantageous to MIP. For this reason, the use of MIP has so far been safer than other methods. The application of MIP is also applicable to the extraction and analysis of samples. For some analysts/users, the extraction step is laborious, not only chemicals used but also the time and effort needed. The MIPSPE would be more effective. Therefore, the improvement of this innovative SPE should be made to achieve not only acceptable but also reliable results. The following future, probably the validation step, is an improvement to achieve better MIPSPE quality than previously reported. Furthermore, the MIP-based sensor technology showed the robust performance of the soya sauce even though the old-fashionable electrode systems are still used. Further research, therefore, requires the use of a screen-printed electrode to make the sensor more portable. Testing on actual samples is also required in a variety of foods containing 3-MCPD or bound 3MCPD.

\section{Acknowledgments}

The authors thanked the Semnas Bioteknologi 2020 committee for allowing our review to be presented.

\section{References}

Abraham K, KE Appel, E Berger-Preiss, E Apel, S Gerling, H Mielke \& A Lampen (2013). Relative oral bioavailability of 3-MCPD from 3-MCPD fatty acid esters in rats. Arch Toxicol $87(4)$, 649-659. https://doi.org/10.1007/s00204-012-0970-8

Andres S, KE Appel \& A Lampen (2013). Toxicology , occurrence and risk characterisation of the chloropropanols. Food Chem Toxicol 58, 467-478. https://doi.org/10.1016/j.fct.2013.05.024

Barocelli E, A Corradi, A Mutti \& PG Petronini 
(2011). 90-day toxicological study of 3-MCPD and its dipalmitate. EFSA (178), 1-131.

Becalski A, S Feng, BPY Lau \& T Zhao (2015). A pilot survey of 2- and 3monochloropropanediol and glycidol fatty acid esters in foods on the Canadian market 20112013. J Food Compos Anal 37, 58-66. https://doi.org/10.1016/j.jfca.2014.09.002

Cerbulis J, OW Parks, RH Liu, EG Piotrowski \& HM Farrell (1984). Occurrence of diesters of 3chloro-1, 2-propanediol in the neutral lipid fraction of goats' milk. J Agric Food Chem 32(3), 474-476. https://doi.org/10.1021/jf00123a013

Cho WS, BS Han, KT Nam, K Park, M Choi, SH Kim \& DD Jang (2008). Carcinogenicity study of 3-monochloropropane-1,2-diol in SpragueDawley rats. Food Chem Toxic 46(9), 31723177. https://doi.org/10.1016/j.fct.2008.07.003

Custodio-Mendoza JA, RA Lorenzo, IM Valente, PJ Almeida, MA Lage, JA Rodrigues \& AM Carro (2018). Development of a partitioned liquid-liquid extraction- dispersive solid phase extraction procedure followed by liquid chromatography-tandem mass spectrometry for analysis of 3-monochloropropane-1,2-diol diesters in edible oils. J Chroma A 1548, 1926.

https://doi.org/10.1016/j.chroma.2018.03.017

De Smet D, P Dubruel, C Van Peteghem, E Schacht \& S De Saeger (2009). Molecularly imprinted solid-phase extraction of fumonisin $\mathrm{B}$ analogues in bell pepper, rice and corn flakes. Food Addit Contam 26(6), 874.

EU (2014). Analysis of occurrence of 3monochloropropane-1, 2-diol (3-MCPD) in food in Europe in the years 2009-2011 and preliminary exposure assessment. Official Journal of the European Union 57(L271), 9395. https://doi.org/10.2903/j.efsa.2013.3381

EU (2018). Regulation (EC) No 1881/2006 as regards maximum levels of glycidyl fatty acid esters in vegetable oils and fats, infant formula, follow-on formula and foods for special medical purposes intended for infants and young children. Official Journal of the European Union 61(L55), 27-29. https://doi.org/10.2903/j.efsa.2016.4426

Fang M, L Zhou, H Zhang, L Liu \& ZY Gong (2019). A molecularly imprinted polymers/carbon dots-grafted paper sensor for 3-monochloropropane-1,2-diol determination. Food Chem 274, 156-161. https://doi.org/10.1016/j.foodchem.2018.08.13 3

Franke K, U Strijowski, G Fleck \& F Pudel (2009). Influence of chemical refining process and oil type on bound 3-chloro-1,2-propanediol contents in palm oil and rapeseed oil. LWT Food Sci Tech 42(10), 1751-1754. https://doi.org/10.1016/j.lwt.2009.05.021

Hrncirik K \& G van Duijn (2011). An initial study on the formation of 3-MCPD esters during oil refining. Eur J Lipid Sci Technol 113(3), 374379. https://doi.org/10.1002/ejlt.201000317

Hu Z, P Cheng, M Guo, W Zhang \& Y Qi (2013). A novel approach of periodate oxidation coupled with HPLC-FLD for the quantitative determination of 3-chloro-1,2-propanediol in water and vegetable oil. J Agric Food Chem 61(27), 6614-6621. https://doi.org/10.1021/jf400167f

IARC (2013). Some chemicals present in industrial and consumer products, food and drinking-water. IARC (Vol. 101).

Jeong J, BS Han, WS Cho, M Choi, CS Ha, BS Lee \& CY Kim (2010). Carcinogenicity study of 3monochloropropane-1, 2-diol (3-MCPD) administered by drinking water to $\mathrm{B} 6 \mathrm{C} 3 \mathrm{~F} 1$ mice showed no carcinogenic potential. Arch Toxicol 84(9), 719-729. https://doi.org/10.1007/s00204-010-0552-6

Lanovia T, N Andarwulan \& P Hariyadi (2014). Validasi modifikasi metode WeIßhaar untuk analisis 3-MCPD ester dalam minyak goreng sawit. Jurnal Teknologi Dan Industri Pangan 25(2), 200-208. https://doi.org/10.6066/jtip.2014.25.2.200

Leung MKP, BKW Chiu \& MHW Lam (2003). Molecular sensing of 3-chloro-1,2-propanediol by molecular imprinting. Analytica Chimica Acta 491(1), 15-25. https://doi.org/10.1016/S00032670(03)00792-X

Li C, SP Nie, Zhou, Y Qiang \& MY Xie (2015). Exposure assessment of 3monochloropropane-1, 2-diol esters from edible oils and fats in China. Food Chem Toxicol 75, 8-13. https://doi.org/10.1016/j.fct.2014.10.003

Li Y, C Zheng, X Sun, B Ouyang, P Ni \& Y Zhang (2014). Identification of 3-chloro-1,2propandiol using molecularly imprinted composite solid-phase extraction materials. Anal Bioanal Chem 406(25), 6319-6327. https://doi.org/10.1007/s00216-014-8059-2

Mane S, S Ponrathnam \& N Chavan (2015). Effect of chemical cross-linking on properties of polymer microbeads: A review. Can Chem Trans 3(4), 473.

Matthäus B \& F Pudel (2013). Mitigation of 3MCPD and glycidyl esters within the production chain of vegetable oils especially palm oil. Lipid Technol 25(7), 151-155. https://doi.org/10.1002/lite.201300288 
Mayes AG \& K Mosbach (1996). Molecularly imprinted polymer beads: suspension polymerization using a liquid perfluorocarbon as the dispersing phase. Anal Chem 68(21), 3769 .

Mijangos I, F Navarro-Villoslada, A Guerreiro, E Piletska, I Chianella, K Karim \& S Piletsky (2006). Influence of initiator and different polymerisation conditions on performance of molecularly imprinted polymers. Biosensors and Bioelectronics 22(3), 381.

Munawar H, A Garcia-Cruz, M Majewska, K Karim, W Kutner \& S Piletsky (2020). Electrochemical determination of fumonisin B1 using a chemosensor with a recognition unit comprising molecularly imprinted polymer nanoparticles. Sensors and Actuators B: Chemical 321, 128552. https://doi.org/10.1016/j.snb.2020.128552

Munawar H, JS Mankar, MD Sharma, A GarciaCruz, LAL Fernandes, M Peacock \& RJ Krupadam (2020). Highly selective electrochemical nanofilm sensor for detection of carcinogenic PAHs in environmental samples. Talanta 219, 121273. https://doi.org/10.1016/j.talanta.2020.121273

Razak R, A Kuntom, WL Siew, NA Ibrahim, MR Ramli, R Hussein \& K Nesaretnam (2012). Detection and monitoring of 3monochloropropane-1,2-diol (3-MCPD) esters in cooking oils. Food Control 25(1), 355-360. https://doi.org/10.1016/j.foodcont.2011.10.05 8

Retho C \& F Blanchard (2005). Determination of 3-chloropropane-1,2-diol as its 1,3-dioxolane derivative at the $\mu \mathrm{g} / \mathrm{kg}$ level: Application to a wide range of foods. Food Addit Contam 22(12), 1189-1197.

Scholsky KM (1993). Polymerization reactions at high pressure and supercritical conditions. $J$ Supercrit Fluids 6(2), 103-127. https://doi.org/10.1016/0896-8446(93)90025S

Sun X, L Zhang, H Zhang, H Qian, Y Zhang, L Tang \& Z Li (2014). Development and application of 3-chloro-1,2-propandiol electrochemical sensor based on a polyaminothiophenol modified molecularly imprinted film. J Agric Food Chem 62(20), 4552-4557. https://doi.org/10.1021/jf4055159

Suwastoyo B (2020). Forum seeks to help industries prepare to meet 3-MCPD and GE ceiling levels. Retrieved August 26, 2020, from https://thepalmscribe.id/forum-seeks-to-helpindustries-prepare-to-meet-3-mcpd-and-geceiling-levels/\#: :text=In February 2018\%2C the European,forces on January 1\%2C 2020.

Van Duuren BL, BM Goldschmidt, C Katz, I
Seidman \& JS Paul (1974). Carcinogenic activity of alkylating agents. J Natl Cancer Inst 53(3), 695-700.

https://doi.org/10.1093/jnci/53.3.695

Wang L, Y Ying, Z Hu, T Wang, X Shen \& P Wu (2016). Simultaneous determination of 2- And 3-MCPD esters in infant formula milk powder by solid-phase extraction and GC-MS analysis. J AOAC Internat 99(3), 786-791. https://doi.org/10.5740/jaoacint.15-0310

Weisburger EK, BM Ulland, JM Nam, JJ Gart \& JH Welsburger (1981). Carcinogenicity tests of certain environmental and industrial chemicals. $J$ Natl Cancer Inst 67(1), 75-88. https://doi.org/10.1093/jnci/67.1.75

Weißhaar R (2008). Determination of total 3chloropropane-1,2-diol (3-MCPD) in edible oils by cleavage of MCPD esters with sodium methoxide. Eur J Lipid Sci Technol 110(2), 183-186.

https://doi.org/10.1002/ejlt.200700197

Wong A, MV Foguel, S Khan, FM De Oliveira, CRT Tarley \& MDPT Sotomayor (2015). Development of an electrochemical sensor modified with Mwent-Cooh and Mip for detection of diuron. Electrochim Acta 182, 122-130.

https://doi.org/10.1016/j.electacta.2015.09.054

Xu M, Z Jin, Z Yang, J Rao \& B Chen (2020). Optimization and validation of in-situ derivatization and headspace solid-phase microextraction for gas chromatography-mass spectrometry analysis of 3-MCPD esters, 2MCPD esters and glycidyl esters in edible oils via central composite design. Food Chem 307, 125542

https://doi.org/10.1016/j.foodchem.2019.1255 42

Yaman YT, G Bolat, TB Saygin \& S Abaci (2020). Molecularly imprinted label-free sensor platform for impedimetric detection of 3-monochloro propane--1,2--diol. Sensors \& Actuators: $\quad$ B. $\quad$ Chemical, 128986. https://doi.org/10.1016/j.snb.2020.128986

Yu C \& K Mosbach (2000). Influence of mobile phase composition and cross-linking density on the enantiomeric recognition properties of molecularly imprinted polymers. J Chromatgr $888(1), 63$.

Zelinková Z, B Svejkovská, M Velíšek \& M Doležal (2006). Fatty acid esters of 3chloropropane-1,2-diol in edible oils. Food Addit Contam 23(12), 1290-1298. https://doi.org/10.1080/02652030600887628

Zhou H, Q Jin, X Wang \& X Xu (2014). Effects of temperature and water content on the formation of 3-chloropropane-1,2-diol fatty acid esters in palm oil under conditions simulating deep fat 
Menara Perkebunan 2021, 89(1), 62-72

frying. Eur Food Res Technol 238(3), 495-501. https://doi.org/10.1007/s00217-013-2126-3

Zulkurnain M, O Ming, R Abdul, I Arbi, T Chuan \& C Ping (2012). The effects of physical refining on the formation of 3- monochloropropane-1, 2-diol esters in relation to palm oil minor components. Food Chem 135(2), 799-805. https://doi.org/10.1016/j.foodchem.2012.04.14 4 